Marquette University

e-Publications@Marquette

$1-1-2015$

\title{
The Impact of Output and Exchange Rate Volatility on Fixed Private Investment: Evidence from Selected G7 Countries
}

Abdur Chowdhury

Marquette University, abdur.chowdhury@marquette.edu

Mark Wheeler

Western Michigan University

Accepted version. Applied Economics, Vol. 47, No. 25 (2015): 2628-2641. DOI. (C) 2015 Taylor and Francis (Routledge). Used with permission. 


\title{
Marquette University
}

\section{e-Publications@Marquette}

\section{Economics Faculty Research and Publications/Department of Economics}

This paper is NOT THE PUBLISHED VERSION; but the author's final, peer-reviewed manuscript. The published version may be accessed by following the link in the citation below.

Applied Economics, Vol. 47, No. 25 (2015): 2628-2641. DOI. This article is (C) Taylor and Francis (Routledge) and permission has been granted for this version to appear in e-Publications@Marquette. Taylor and Francis (Routledge) does not grant permission for this article to be further copied/distributed or hosted elsewhere without the express permission from Taylor and Francis (Routledge).

\section{The Impact of Output and Exchange Rate Volatility on Fixed Private Investment: Evidence from Selected G7 Countries}

\author{
Abdur R. Chowdhury \\ Department of Economics, Marquette University, Milwaukee, WI \\ Mark Wheeler \\ Department of Economics, Western Michigan University, Kalamazoo, MI
}

\section{Abstract}

This study examines the impact of shocks to exchange rate and output uncertainty (volatility) on real private fixed investment (FI) in Canada, Germany, the United Kingdom and the United States. The analysis is conducted using vector autoregressive models that contain the price level, real output, the volatility of real output, the real exchange rate, the volatility of the real exchange rate, an interest rate and FI. The results yield important public policy implications with regard to the impact of output volatility of Fl. Our analysis indicates that volatility shocks, measured as output volatility or exchange rate volatility, do not have a significant impact on FI for any country in our study. 


\section{Keywords:}

fixed investment, exchange rate volatility, G7 countries, VAR model, variance decomposition

\section{Introduction}

Macroeconomic uncertainty may affect economic growth through several channels. The overall effect may, in principle, be positive, negative, or zero. A study of these channels would have particular significance for our understanding of economic stability and policy. One channel that has attracted attention is the effect of macroeconomic uncertainty on the fixed private investment decisions of firms. This increased interest can partly be explained by the increasing integration of global financial markets, whereby domestic variables are more sensitive to changes in both internal and external markets.

The literature on investment and uncertainty shows that the predictions about the sign of the uncertainty-investment link depend heavily on what assumptions go into one's model. If one assumes perfect competition, costless adjustment of factors other than capital, and constant returns to scale, then uncertainty actually raises the expected profitability of capital and therefore should lead to higher investment (Abel, 1983). More recent work (Dixit and Pindyck, 1994) shows that when one assumes that investments are irreversible, firms can be prompted to delay investments out of the fear that the economic environment might change for the worse. Serven (1998), however, showed that to demonstrate a negative link between uncertainty and investment, one needs to assume not only irreversibility but also either risk aversion, imperfect competition or decreasing returns to scale.

Relative to the analytical literature, empirical studies on uncertainty and investment are not conclusive in their assessment of the impact of uncertainty on investment. In most cases, these studies use naïve measures of sample variability rather than uncertainty, often ignore important investment determinants and sometimes fail to consider the likely simultaneity between investment and its determinants (Serven, 1998).

This article fills the gap in the literature by re-examining the link between macroeconomic uncertainty and fixed private investment in several developed countries. The article looks at two different types of uncertainty - one emanating from the domestic economy and the other reflecting uncertainty in the foreign economy - measured by output and real exchange rate uncertainty (volatility).

To our knowledge, no other study has included two alternative sources of uncertainty in the same model. Moreover, by selecting the United States, a euro zone country (Germany), a non-eurozone country (United Kingdom) and a relatively open economy in North America (Canada), the article examines whether the investment-uncertainty link is sensitive to any specific characteristic of the country.

A number of studies have shown that exchange rate volatility translates into a high degree of uncertainty for private investors regarding both the profitability and the cost of investment. Volatile real exchange rates are associated with erratic swings in the relative profitability of investment in the traded and nontraded goods sectors of the economy. In turn, the cost of new capital goods also becomes uncertain with real exchange rate volatility, due to the high import content of investment in developing countries (Serven, 1999). 
This article is organized as follows. Section II reviews the literature. A theoretical model is developed in Section III, while preliminary data analysis is performed in Section IV. Section V describes the methodology employed. The empirical results are given in Section VI. Robustness checks are performed in Section VII. This article ends with concluding remarks in Section VIII.

\section{Literature Review}

Economic theory does not yield unambiguous conclusions regarding the effect of uncertainty on investment: an increase in uncertainty might either increase or decrease investment. Early neoclassical models of a positive uncertainty-investment relation rely on the assumption that investment is reversible. If investment decisions are reversible as new information becomes available, the existence of uncertainty that affects marginal productivity of capital would increase the optimal capital stock and, hence, investment (Hartman, 1972; Abel, 1983). These authors have suggested that greater price uncertainty can lead competitive risk-neutral firms to increase investment.

On the other hand, when irreversibility is present, the value of the firm is enhanced by the value of a call option representing the firm's unexploited investment opportunity (Dixit and Pindyck, 1994). This may cause the uncertainty-investment relationship to be negative. The literature on irreversible investment (Pindyck, 1991) shows that increased uncertainty retards investment by risk-neutral firms if (i) the cost of reducing the capital stock is higher than the upward adjustment cost, and (ii) firms operate in imperfectly competitive market (Caballero, 1991). Under these conditions, an increase in price uncertainty causes firms to regret having too much capital relative to having too little. The firms respond by investing less. Risk aversion (Craine, 1989) and credit rationing (Greenwald et al., 1984) have also been given as possible reasons to explain why greater uncertainty could reduce investment.

An extensive literature on investment and uncertainty is provided in Carruth et al. (2002). They suggest that there is reasonable consensus in the empirical literature that the effect of uncertainty on aggregate investment is negative. Lee and Shin (2001) suggest that the balance between the positive and negative effects of uncertainty may depend on the labour share of firms' cost.

Since the breakdown of the fixed exchange rate system in 1972, both real and nominal exchange rates have fluctuated widely. It has been shown that flexible exchange rates can lead to excessive short-term volatility and episodes of currency misalignments. Courchene and Harris (1999) suggest that while floating exchange rates are a smaller problem for commodity producers, because most resource exports are already priced in US dollars, and currency hedging is relatively straight forward, the lack of longer-run hedging facilities can make exchange rate movements problematic for the manufacturing sector. Thus, flexible exchange rates provide inherently volatile and unpredictable cost structures.

In addition, most exchange rate movements are unexpected as shown by fragility of exchange rate forecasting models and the inability of market indicators, such as interest rate differentials and forward rates, or market surveys, to anticipate major changes. However, it should be pointed out that the fact that exchange rate changes have been larger than expected, and not very predictable, does not necessarily imply that they have been harmful. The more pronounced exchange rate movements in recent years may have been needed to absorb the economic shocks. 
Using a large sample of industries, Goldberg (1993) discovered that the effects of the exchange rate and its volatility on investment in the United States are more visible in the 1980s than in the 1970s. In the 1980s, the dollar movements had differentiated impacts on industries. Dollars movements had ambiguous effects on nonmanufacturing industries, and its depreciations (appreciations) decreased (increased) investment in manufacturing nondurables sectors.

Campa and Goldberg $(\underline{1995}, 1997,1999)$ analyse how the exchange rate could affect the investment and pricing behaviour of manufacturing firms in the United States, Canada, Japan and the United Kingdom. They use a model of investment with adjustment costs that takes into account export sales and the use of imported inputs in production, both of which expose producers to exchange rate movements. Investment is a function of the marginal productivity of capital. Exchange rate changes can affect profitability by passing through into home and export market prices and imported input prices. The impact of exchange rate movements on profitability and investment decisions depends on the firm's international orientation and the competitive structure of the industry. Highly competitive industries are expected to exhibit larger responsiveness to exchange rates.

Campa and Goldberg (1995) show that the effect of the exchange rate on investment can change as patterns of external exposure shift over time. While US manufacturing sectors were primarily export, exposed in the 1970s, they became predominantly import-exposed by the early 1980s. Consequently, exchange rate appreciations reduced investment in durable goods sectors in the $1970 \mathrm{~s}$, but stimulated investment after 1983. When exchange rate volatility depressed investment, the effects were small. Campa and Goldberg (1999) extend their estimation model for the two-digit manufacturing sectors of the United States, United Kingdom, Canada and Japan. They find that, across countries, exchange rates tend to have insignificant effects on investment in high markup sectors. Investment responsiveness to exchange rates is fairly strong in low markup sectors.

In Darby et al. (1999), long-run investment in Germany and France is found to be negatively affected by exchange rate uncertainty, while there is weaker evidence for Italy and the United Kingdom and no evidence for the United States. Recent work by Darby et al. (2002) highlights the impact of exchange rate misalignment on investment and finds evidence of nonlinearities and asymmetries. However, when volatility is measured after extracting the trend component of the real exchange rate, volatility in the United States has a positive effect.

Byrne and Davis (2003) provide evidence for similarities across the $\mathrm{G} 7$ in the negative response of investment to uncertainty in nominal and real effective exchange rates estimated using GARCH and Pooled Mean Group Panel Estimation. This article noted that to the extent EMU favours lower exchange rate volatility, it is beneficial to investment.

The conventional wisdom that exchange rate uncertainty reduces investment has been challenged. It has been argued that firms are risk averse and cannot completely hedge against exchange rate movements, especially over the longer horizon relevant for investment (Emerson et al., 1992). Building on the Dixit-Pindyck approach, Darby et al. (1999) show that more exchange rate variability can actually increase investment. This can happen in industries where the scrapping price of any investment is low and the risk of being left with an unwanted capital is high. This can also occur when the increase in uncertainty is large or when the initial environment is one of low uncertainty, and the opportunity cost of waiting, rather than investing, is high. 
Greater exchange rate stability would encourage investment in industries with relatively lower productivity, high scrapping value and low opportunity costs of waiting (e.g., service industries). However, greater exchange rate stability would tend to reduce investment in industries with low scrapping prices (e.g., public utilities) or high entry costs (e.g., high tech and R\&D) or in industries with high scrapping values combined with high opportunity costs of waiting (e.g., financial services). The exchange rate could also affect investment by its effect on the cost of imported capital goods or by its effect on the competitive environment (Lafrance and Schembri, 2000).

In complementary work, Serven (2003), using GARCH measures of uncertainty, found that real exchange rate uncertainty has a significant impact on investment using evidence from the developing countries. The impact was larger at higher levels of uncertainty underscoring 'threshold effects'. Moreover, the investment effect of real exchange rate uncertainty was shaped by the degree of trade openness and financial development. Higher openness and weaker financial systems are associated with a more significantly negative uncertainty-investment link. Nucci and Pozzolo (2001) extend earlier works and show that permanent changes in the exchange rate are important for the level of investment, while changes in the transitory component are not.

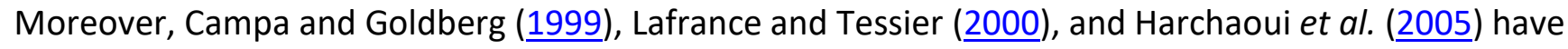
found that investment does not respond to the exchange rate in Canada. But further investigations of Harchaoui et al. (2005) highlight the existence of nonlinear effects of exchange rate on investment. Exchange rate depreciations (appreciations) have positive (negative) effects on investment when the exchange rate volatility is low. This reveals the necessity of differentiating investment response between high and low exchange rate volatility in Canada. Beside these studies on industries or at the firm level, Darby et al. (1999) use aggregated investment data for five countries (France, Germany, Italy, the United Kingdom and the United States) and finds that exchange rate volatility has a large negative effect on investment. Its impact is more important than that of exchange rate misalignment. Exchange rate stability would raise investment in Europe, in general, although France and Germany would benefit more, while Italy and United Kingdom would enjoy only temporarily gains.

The discrepancy between empirical results and general predictions of the previous models calls for a fresh look at the relationship between exchange rate uncertainty and investment. In a previous paper, Chowdhury and Wheeler (2008) analysed the impact of relative exchange rate volatility on foreign direct investment (FDI). This article continues the research agenda to unravel the implications of exchange rate volatility on domestic investment. We do this using variance decompositions (VDCs) derived from vector autoregressive (VAR) models for Canada, Germany, the United Kingdom and the United States.

To help in making comparisons across countries, a common specification is used. The VAR for each country contains the growth rate of real private fixed investment, the growth rate of real GDP, the inflation rate, a long-term interest rate, the volatility (uncertainty) of real GDP and the volatility of the real exchange rate. A common lag of eight is used for each model. VDCs are derived using a short-run (Choleski) identification scheme. 


\section{Theoretical Model}

In this section, we develop a theoretical model building on the impact of exchange-rate led demand uncertainty on investment decisions, in the line of Ogawa and Suzuki (2000) and Guérin and LahrècheRévil (2001). We show that the influence of exchange rate uncertainty depends on the external exposure of the firm, which sells or buys on foreign markets. Hence, the 'openness ratio' of the firm is the fundamental transmission channel of exchange rate uncertainty on investment (and production) behaviour. Moreover, this model also underlines the importance of market structures in negative impact of uncertainty on profits and investment.

The firm produces a good which can be sold both on the domestic and foreign markets. We suppose that the firm has already built the productive capacity to meet the domestic demand and focus on its strategy when investing for selling abroad. The price in national currency, $p$, is exogenous. If the foreign demand function takes a CES form with an elasticity of substitution $s$ between domestic and foreign goods and if the market share of domestic producers in foreign markets is small, the foreign demand for domestic exports can then be written as follows:

$$
D=A e^{\sigma}
$$

where $A$ is a constant, $e$ is the nominal exchange rate (an increase denotes an appreciation), which is i.i.d. on the interval $\left[1-s_{1} ; 1+s_{1}\right]$ and $\sigma>1$.

The firm has a two-period horizon. It sets its production capacity choice $Q$ (therefore the desired investment level) in period 1 and faces a marginal investment and production cost expressed in national currency, $c$. In period 2, it sells the maximum quantity on the foreign market, all remaining produced goods being definitively lost. This assumption follows from the fact that domestic conditions determine the pricing of the firm for all markets. Although there is evidence of export pricing to market strategies, the resolution in a general equilibrium framework of price determination would not change the intuition behind the model.

The expected profit of the firm is

$$
V=-c Q+p E(S)
$$

where $S=\min (D, Q)$.

For a given level of production $Q$, there is $e_{Q}$ so that

First case: for $e<e_{0}, D<Q$. In this case, the profit of the firm is

$$
\Pi_{1}=p D-c Q(3)
$$


Second case: for $e>e_{Q}, D>Q$. In this case, the profit of the firm is

$\prod_{2}=(p-c) Q(4)$

For a given level of production $Q$, the expected profit of the firm is

$E\left(\prod\right)=p_{1}\left[p E_{1}(D)-c Q\right]+p_{2}[(p-c) Q](5)$

with $p_{1}$ probability of case 1 and $p_{2}=1-p_{1}$ the probability of case 2 .

When there is no risk aversion, the firm sets $Q$ to maximize the expected profit. With

$D=A e^{\sigma}$, the production level set by the firm is such that

$\left.Q \in\left[A\left(1-s_{1}\right)^{\sigma} ; A\left(1+s_{1}\right)^{\sigma}\right] 6\right)$

If this condition is met, $e_{Q}=(Q / A)^{1 / \sigma}$. Then following Ogawa and Suzuki $(\underline{2000})$, once $E(\Pi(Q))$ is known, the optimal production level could be determined -

$Q^{*}=A\left[\left(1+s_{1}\right)-2 s_{1} c / p\right]^{\sigma}(7)$

This optimum production level belongs to the definition domain $\left[A\left(1-s_{1}\right)^{\sigma} ; A\left(1+s_{1}\right)^{\sigma}\right]$ if $p>c$, which is also the condition for $E(\Pi)>0.1$

As soon as $p<2 c / s_{1}$, the production level set by the firm is a decreasing function of $s_{1}$, i.e., of volatility. Hence, as long as we suppose a 'normal' level of volatility (for instance between 0 and $20 \%$ ) and a reasonable level of gross margins (less than 50\%), exchange rate volatility has a negative impact on investment. Moreover, the sensitivity of production to volatility decreases with the ratio $c / p$ : the more important the mark-up (i.e. $p / c$ ), the less important the negative influence of exchange rate volatility. In other words, when there is a strong cost advantage, the risk induced by volatility weights less than the potential benefits due to increased sales. This result comes from the convexity of the demand function towards the exchange rate and must be handled with care: when dynamic strategic interactions are taken into account, the reverse may be observed as firms with strong market power may feel able to afford to wait (and decrease the risk) before investing.

Mark-ups strongly vary across industries and countries: Oliveira-Martins et al. (1996) find they are substantially lower in fragmented industries (low sunk-costs oligopolistic sectors; numerous agents) than in segmented industries (high sunk-costs oligopolistic sectors; few competitors). So, even without taking into account the export pricing to markets strategies, the specialization of a given country affects its reaction to exchange rate volatility.

Consistent with previous literature, our theoretical model shows that the impact on volatility on investment is an empirical question. Depending on the situation faced by a given firm, or country, the impact of a volatility shock on investment can be positive, negative or insignificant. 


\section{Model}

Variables and preliminary data analysis

The VAR model used for each country contains seven endogenous variables. With the exception of the long-term interest rate and the exchange rate, all data are taken for the FRED data base maintained by the Federal Reserve Bank of St. Louis. Data on the long-term interest rate and the exchange rate are taken from the OECD's Main Economic Indicators (MEI) CDRom.

The main variable of interest is real private fixed investment (FI). Depending on the country, we use fixed private investment divided by the GDP deflator or gross fixed capital formation divided by the GDP deflator, as our measure of FI. $\underline{2}$ The general price level $(P)$ in each country is thought to influence investment. We measure the price level with the GDP deflator. Accelerator theories of investment posit that output is a major determinant of investment. Hence, we include real GDP (RGDP) in each country's model. To capture the impact of the uncertainty associated with economic activity of investment decisions, we also include the conditional variance of the log of GDP (HGDP).

Traditional theories of investment indicate that investment decisions depend, in part, on the long-term rate of interest. Hence, our models for Canada, Germany, the United Kingdom and the United States contain a long-term rate of interest (LR). We define the long-term interest rate as the 10-year

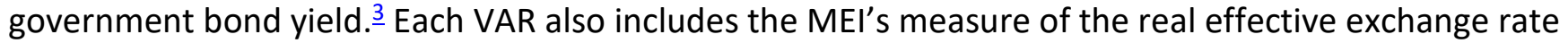
(REX) and the volatility of the real exchange rate (HREX). ${ }^{4}$ We use the conditional variance of the log of each country's real effective exchange rate as our measure of exchange rate volatility. With the exception of $L R$, all data are seasonally adjusted. $\underline{5}$ Quarterly data are used.

A series of Dickey and Fuller (1979) and Kwiatkowski et al. (1992) unit root tests confirms that, for each country in the study, the log level of FI, P, RGDP and REX are each integrated of order one [/(1)] and should be difference once before the estimation of a given country's VAR model. This leaves us with FI, RGDP and REX specified in growth rates, and $P$ specified as the inflation rate.

HRGDP and HREX are derived from the residuals of ARIMA models and are, by definition, covariance stationary. We assume that $L R$ is covariance stationary for each country. As many have noted, an interest rate that is not stationary in levels would be an interest rate that tends towards infinity in the long-run. Hence, LR, HGDP and HREX enter the models in levels.

We have conducted the rank test for cointergation due to Johansen (1988) and Johansen and Juselius (1990) using the I(1) variables for each country. Johansen's $(\underline{2000}, \underline{2002})$ small sample correction is employed in each case. These tests reveal that cointegration is not present in our models for the United Kingdom and the United States. However, one cointegrating vector exists in our models for Canada and German. Because of this, the models for Canada and Germany are estimated as VAR models in error correction form. That is, for Canada and Germany, we estimate vector error correction models using an Engle and Granger (1987) two-step estimator.

We restrict our estimation period to the post-Bretton Woods era. Hence, we do not use data before 1972:1 for any country in our study. The estimation period ends in 2011:2 for each country. After allowing for presample data for estimation of HGDP and HREX, and for eight (8) lags in the VAR, 
estimation for Canadian and UK VARs begins in 1974:2, estimation for the US VAR begins in 1974:4, while estimation of the VAR for Germany begins in 1975:2.

Measuring volatility

The conditional variance of the real effective exchange rate (HREX) is used to measure the volatility (uncertainty) associated with the real effective exchange rate (REX) for each country, while the conditional variance of real GDP (HGDP) is used as our measure of the uncertainty associated with real GDP. HGDP and HREX are derived from a generalized autoregressive conditional heteroscedastic $(G A R C H)$ models. For purposes of comparison, we specify a GARCH $(1,1)$ model in each case. The model for the mean of each series is specified with an ARIMA model. Each ARIMA model is selected using traditional Box and Jenkins (1976) methodology. The ARIMA model for the mean of each country's real GDP, together with the GARCH model for the conditional variance of GDP, is reported in Table 1. Table 2 reports the ARIMA model for the mean of each country's REX series, together with the GARCH model for the conditional variance of REX. .6 Our models in Tables 1 and 2 show that there are significant ARCH and GARCH effects in the RGDP and REX for each country in the study.

\section{Table 1. Real GDP forecasts and their associated volatility - HGDP $t$ (absolute value of $t$ -} statistics in parentheses)

$$
\begin{aligned}
& \text { Canada } \\
& \mathrm{GDP}_{t}=\underset{(8.6262)}{0.0073}+\begin{array}{l}
0.36487 e_{t-1} \\
(4.8749)
\end{array}+e_{t} \\
& H_{t}=\begin{array}{l}
0.00001 \\
(2.1872)
\end{array}+\begin{array}{l}
0.3241 e^{2} t-1 \\
(2.8484)
\end{array}+\begin{array}{l}
0.5706 H_{t-1} \\
(5.2648)
\end{array}
\end{aligned}
$$

\section{Germany}

$$
\begin{aligned}
& \mathrm{GDP}_{t}=\begin{array}{l}
0.0048 \\
(4.7167)
\end{array}+\begin{array}{l}
0.6145 G D P_{t-1}-\begin{array}{l}
0.49901 e_{t-1} \\
(2.4946)
\end{array}+e_{t} \\
(1.8053)
\end{array} \\
& H_{t}=\begin{array}{l}
0.0001 \\
(4.4283)
\end{array}+\begin{array}{l}
0.3226 e^{2} t-1 \\
(2.2149)
\end{array}-\begin{array}{l}
0.0592 H_{t-1} \\
(0.6297)
\end{array}
\end{aligned}
$$

\section{United Kingdom}

$$
\begin{aligned}
\mathrm{GDP}_{t}= & \begin{array}{l}
0.0051 \\
(4.1277)
\end{array}+\begin{array}{l}
0.71766 G D P_{t-1}-\begin{array}{l}
0.5638 e_{t-1} \\
(5.3364)
\end{array}+e_{t} \\
(3.3939)
\end{array} \\
H_{t}= & \begin{array}{l}
0.000004 \\
(1.3035)
\end{array}+\begin{array}{l}
0.3295 e^{2} t-1 \\
(2.5348)
\end{array}+\begin{array}{l}
0.6607 H_{t-1} \\
(5.6309)
\end{array}
\end{aligned}
$$

\section{United States}

$$
\begin{aligned}
\mathrm{GDP}_{t}= & \begin{array}{c}
0.0067 \\
(6.3410)
\end{array}+\begin{array}{l}
0.3406 e_{t-1} \\
(4.3389)
\end{array}+\begin{array}{l}
0.2263 e_{t-2} \\
(2.8818)
\end{array}+e_{t} \\
H_{t}= & \begin{array}{l}
0.000005 \\
(1.83099)
\end{array}+\begin{array}{l}
0.1833774610 e^{2} t-1 \\
(2.48500)
\end{array}+\begin{array}{l}
0.7639414645 H_{t-1} \\
(10.93217)
\end{array}
\end{aligned}
$$


Table 2. Real exchange rate movement forecasts and their associated volatility - HREX (absolute value of $t$-statistics in parentheses)

Canada

$$
\begin{gathered}
\operatorname{REX}_{t}=-0.2937 \mathrm{REX}_{t-1}+\begin{array}{l}
0.7679 e_{t-1} \\
(2.3916)
\end{array} e_{t} \\
H_{t}=\underset{(0.3431)}{0.0000002}+\begin{array}{l}
0.0704 e^{2} \\
(1.9293)
\end{array}+\begin{array}{l}
0.9411 H_{t-1} \\
(15.4294)
\end{array}
\end{gathered}
$$

\section{Germany}

$$
\begin{aligned}
\mathrm{REX}_{t}= & \begin{array}{l}
0.2973 \mathrm{REX}_{t-1} \\
(3.9705)
\end{array}+\begin{array}{l}
0.2502 \mathrm{REX}_{t-3}-\begin{array}{l}
0.3226 \mathrm{REX}_{t-4} \\
(3.2798)
\end{array}+e_{t} \\
(4.2114)
\end{array} \\
H_{t}= & \begin{array}{l}
0.0002 \\
(2.6535)
\end{array}+\begin{array}{l}
0.2636 e^{2} \\
(1.7125)
\end{array}-\begin{array}{l}
0.16734 H_{t-1} \\
(0.5776)
\end{array}
\end{aligned}
$$

United Kingdom

$$
\begin{aligned}
\operatorname{REX}_{t}= & 0.30784 \mathrm{REX}_{t-1}+e_{t} \\
& (4.0200) \\
H_{t}= & \begin{array}{l}
0.0016 \\
(8.1284)
\end{array}+\begin{array}{l}
0.0447 e^{2} \\
(1.7240)
\end{array}-\begin{array}{l}
0.9210 H_{t-1} \\
(8.3276)
\end{array}
\end{aligned}
$$

\section{United States}

$$
\begin{aligned}
\mathrm{REX}_{t}= & \begin{array}{l}
1.1394 \mathrm{REX}_{t-1} \\
(5.8430)
\end{array}+\begin{array}{l}
-0.2531 \mathrm{REX}_{t-2} \\
(2.3160)
\end{array}+\begin{array}{c}
-0.8020 e_{t-1} \\
(4.3925)
\end{array}+e_{t} \\
H_{t}= & \begin{array}{l}
0.0002 \\
(2.4383)
\end{array}+\begin{array}{l}
0.3181 e^{2} \\
(2.1504)
\end{array}+\begin{array}{l}
0.1912 H_{t-1} \\
(0.8466)
\end{array}
\end{aligned}
$$

Plots of HGDP and HREX for each country are shown in Figs 1-4. In each case, we restrict the plot of HGDP and HREX to the data used to estimate the corresponding VAR model. Figure 1 shows the plots of conditional variance of RGDP (HRGDP) and the conditional variance of REX (HREX) for Canada. Figure $\underline{2}$ shows plots of HRGDP and HREX for Germany. Figures 3 and $\underline{4}$ shows plots for the United Kingdom and the United States. 
Fig. 1. Volatility of Canadian RGDP and REX

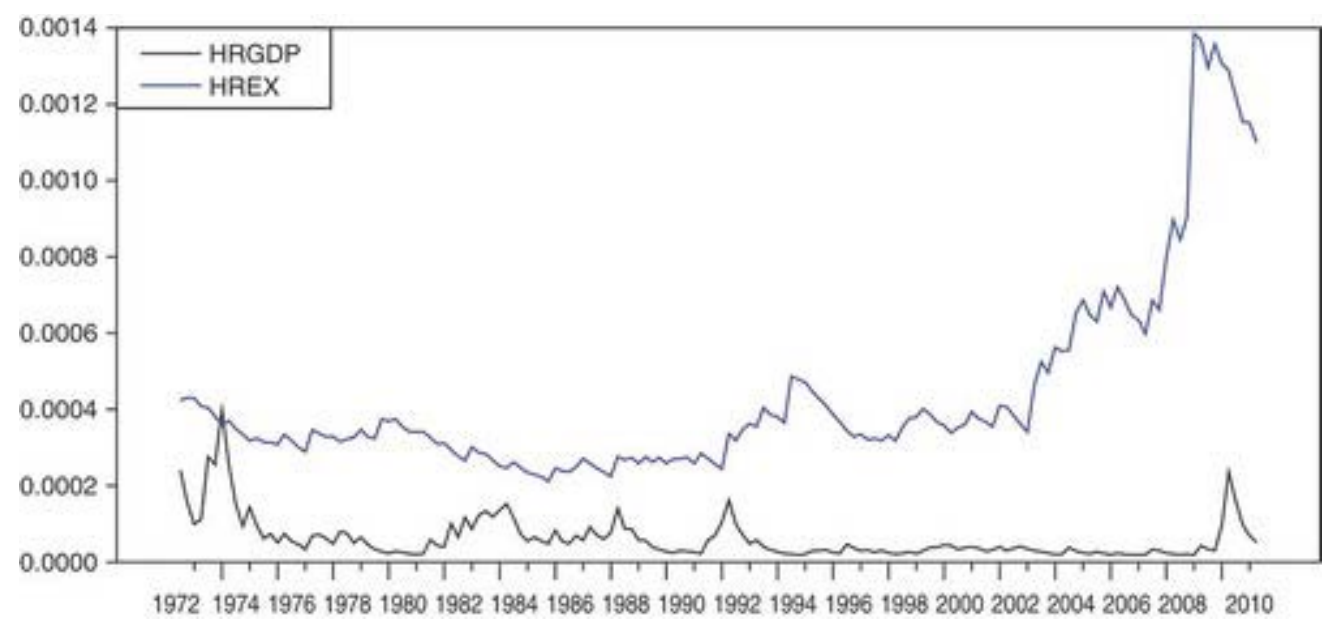

Fig. 2. Volatility of German RGDP and REX

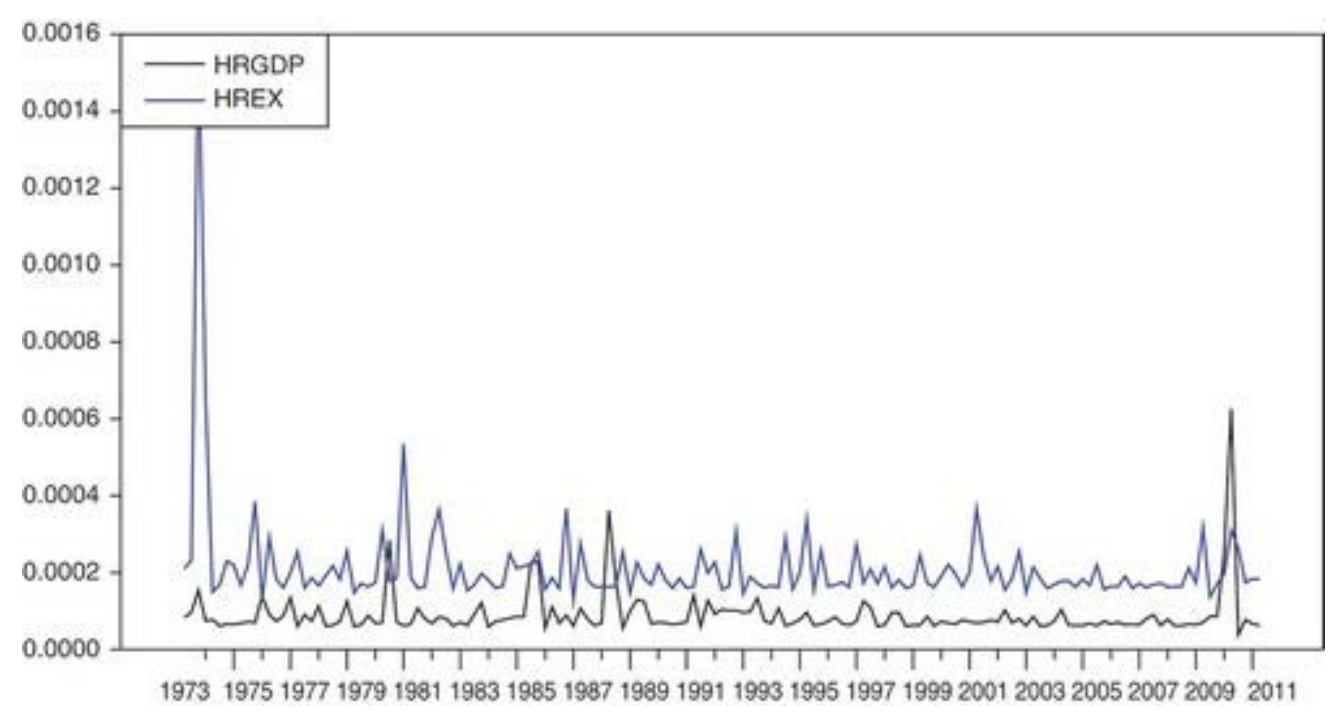

Fig. 3. Volatility of United Kingdom RGDP and REX

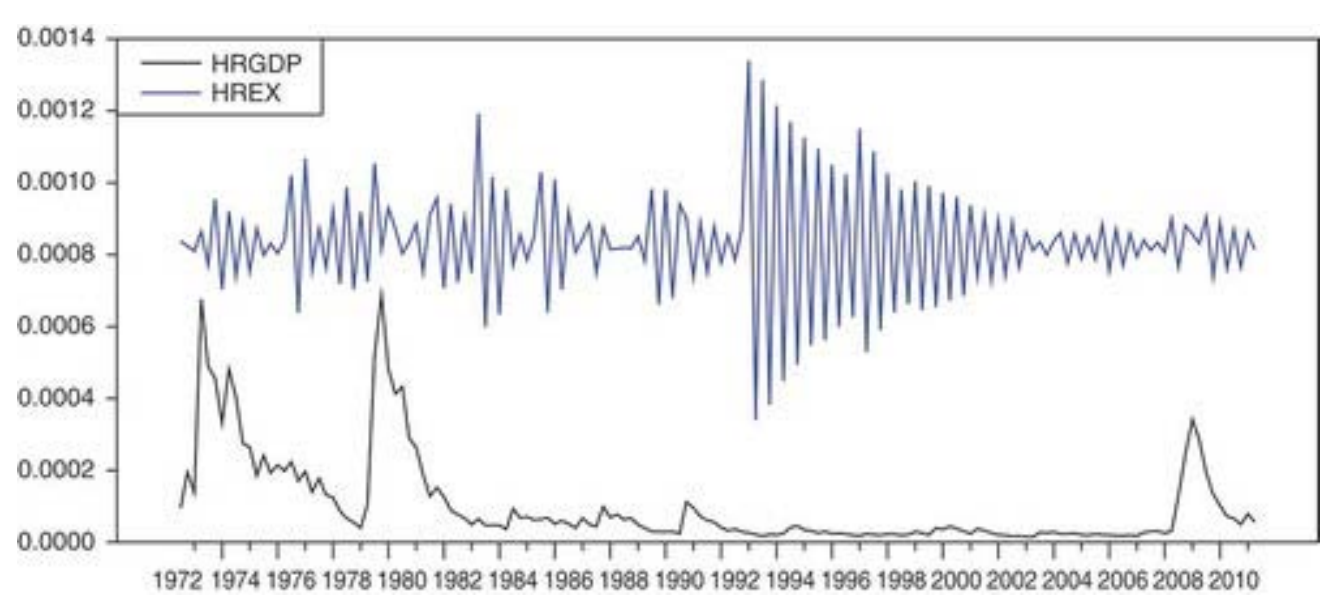


Fig. 4. Volatility of US RGDP and REX

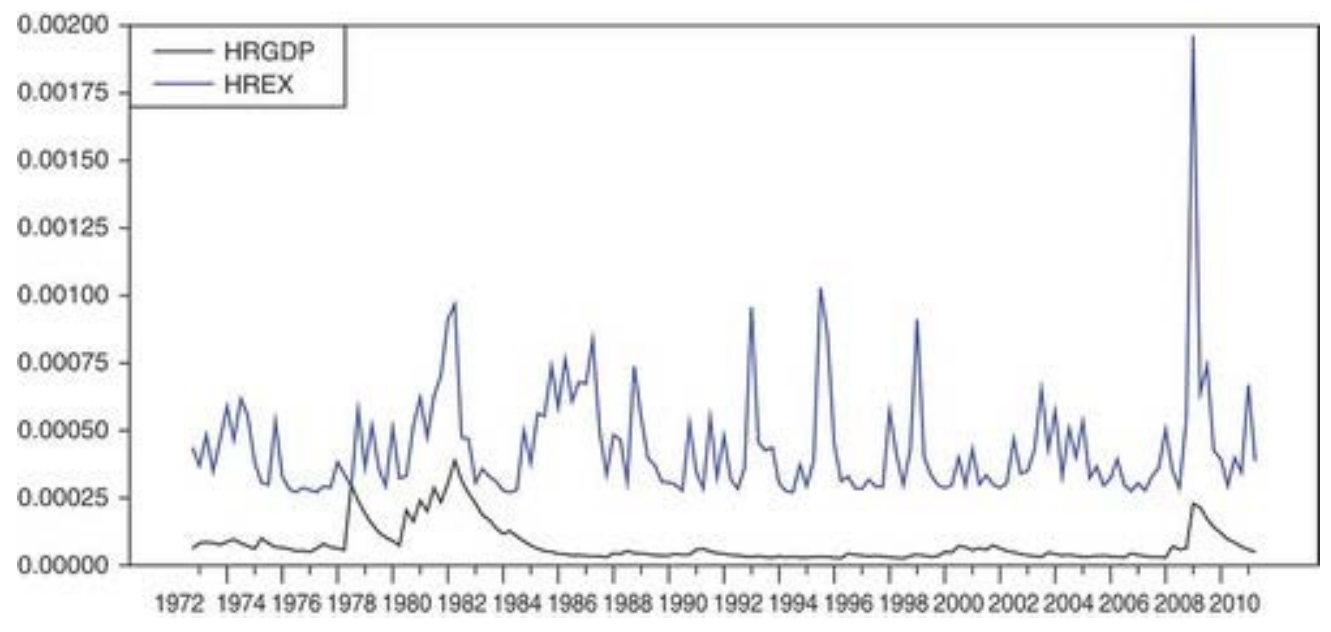

An analysis of Figs 1- 1 reveals some interesting results. Perhaps most interesting, these figures show that, in each country, the uncertainty (volatility) associated with REX exceeds the uncertainty associated with RGDP. The difference is least pronounced in Germany and most pronounced from the United Kingdom. RGDP uncertainty appears to be the largest in the United Kingdom, while Germany has the smallest uncertainty for RGDP.

Figures 1 and $\underline{3}$ indicate that REX has become more volatile in Canada since the launch of the Euro, while in the United Kingdom, the period leading up to the launch of the Euro is associated with increased volatility in REX. Figures 2 and $\underline{4}$ indicate that the launch of the Euro had little impact on the volatility of REX in the Germany and the United States. Most of the volatility in REX for the United States seems to be associated with the bursting of the housing market bubble and the subsequent 'great recession.'

\section{Methodology}

We employ VAR models to examine the impact of a variety of macroeconomic influences on Fl; a lag of eight quarters is used to estimate each model. $\underline{7}$ We examine the relationships among system variables by looking at the response of the system to 'typical' shocks to system variables. A typical shock is defined as a positive 1-SD shock to the residual from a given VAR equation.

One way to examine the impact on system variables of typical shocks is to compute variance decompositions (VDCs). VDCs show the portion of the forecast error variance of each variable in the system that is attributable to its own shocks and to shocks to other system variables. Both direct and indirect effects are captured by VDCs. We are most concerned with the portion of the forecast error variance in FI explained by shocks to P, RGDP, HGDP, REX, HREX and LR.

To compute VDCs, VAR residuals must be orthogonalized. One way to produce orthogonal residuals is to use a Choleski decomposition of contemporaneous relationships. The Choleski decomposition requires that the variables in the VAR be ordered in a particular fashion. Because of cross-equation residual correlation, when a variable higher in the ordering changes, all variables lower in the ordering are assumed to change. $\stackrel{8}{-}$ The extent of the change depends of the degree of the residual correlation. 
Our results are based on the ordering $P, R G D P, H G D P, R E X, H R E X, L R$ and FI. This ordering is consistent with the primary focus of our article. $\mathrm{Fl}$ is placed last in the ordering. This allows shocks to all system variables to have a contemporaneous impact on $\mathrm{Fl}$, but shocks to $\mathrm{FI}$ have no contemporaneous impact on other variables. $\underline{-}$ This is consistent with past investment studies in which current values of explanatory variables have an impact on investment. Based on the efficient markets arguments of Gordon and Veitch (1989), we place financial variables after P and RGDP in the ordering. That is, we place REX, $H$ and $L R$ after $P$ and RGDP in the ordering.

Based on the new Keynesian assumption that, in the short run, output is more flexible than prices, we place $P$ prior to RGDP in the ordering. RGDP is placed above HGDP in the ordering. This allows shocks to the mean of real output to have a contemporaneous impact on the condition variance of real output. REX, HREX and LR are all financial variables. However, REX is made up, in part, by the price levels in the domestic economy and its trading partners, and HREX is derived from REX. Because the price levels in these countries are likely to be sticky, at least in the short run, we place REX and HREX above LR in the ordering. This allows LR to respond contemporaneously to shocks to exchange rate variables. However, exchange rate variables do not respond contemporaneously to changes in LR. Finally, we place REX above HREX in the ordering. This allows REX, the mean of the exchange rate series, to have a contemporaneous impact on HREX, the conditional variance of the exchange rate series.

\section{Empirical Results}

The main results of the article are contained in the VDCs, which are reported in Table 3. SEs were derived using 10000 bootstrap simulations. The estimates of the proportion of the forecast error variance are judged 'significant' if the point estimate is at least twice as large as its SE. VDCs at time horizons of 4, 8, 12, 16 and 20 are reported to convey the dynamics of the system. Because the focus of our study is the determination of $\mathrm{FI}$, we report VDCs for FI only.

\section{Table 3. Variance decompositions of fixed investment Choleski decomposition}




\begin{tabular}{|c|c|c|c|c|c|c|c|}
\hline \multicolumn{2}{|c|}{ Relative variation in } & \multicolumn{6}{|c|}{ Explained by innovations in } \\
\hline Horizon & $P$ & RGDP & HRGDP & REX & HREX & LR & FI \\
\hline \multicolumn{8}{|c|}{ Canadian fixed private investment } \\
\hline 4 & $0.9(3.2)$ & $14.0(5.6)^{*}$ & $1.1(2.5)$ & $3.9(5.7)$ & $5.1(3.1)$ & $19.4(5.6)^{*}$ & $55.6(8.9)^{*}$ \\
\hline 8 & $2.3(4.6)$ & $16.5(6.0)^{*}$ & $4.5(3.0)$ & $7.4(5.8)$ & $6.4(4.6)$ & $17.6(4.6)^{*}$ & $45.3(8.7)^{*}$ \\
\hline 12 & $3.3(4.8)$ & $17.3(6.2)^{*}$ & $4.7(2.8)$ & $9.1(7.3)$ & $6.4(4.8)$ & $16.2(4.5)^{*}$ & $43.0(8.9)^{*}$ \\
\hline 16 & $3.3(5.6)$ & $18.6(6.2)^{*}$ & $4.9(2.8)$ & $9.3(7.5)$ & $7.0(5.4)$ & $15.6(4.7)^{*}$ & $41.3(9.3)^{*}$ \\
\hline 20 & $3.4(6.6)$ & $18.1(6.7)^{*}$ & $5.5(2.8)$ & $9.3(7.9)$ & $7.4(5.8)$ & $16.1(4.8)^{*}$ & $40.2(9.6)^{*}$ \\
\hline \multicolumn{8}{|c|}{ German fixed private investment } \\
\hline 4 & $6.4(4.3)$ & $39.5(7.3)^{*}$ & $1.2(2.7)$ & $1.2(2.3)$ & $4.5(3.1)$ & $1.9(2.2)$ & $45.2(6.2)^{*}$ \\
\hline 8 & $5.1(3.4)$ & $29.6(5.9)^{*}$ & $7.6(4.8)$ & $8.4(4.2)^{*}$ & $6.6(3.6)$ & $6.9(3.1)^{*}$ & $35.6(4.9)^{*}$ \\
\hline 12 & $5.0(3.2)$ & $28.4(5.7)^{*}$ & $9.1(5.0)$ & $9.1(4.6)$ & $6.3(3.5)$ & $7.8(3.3)^{*}$ & $34.2(4.8)^{*}$ \\
\hline 16 & $5.1(3.2)$ & $27.8(5.6)^{*}$ & $9.3(5.2)$ & $10.2(4.8)^{*}$ & $6.1(3.5)$ & $8.5(3.7)^{*}$ & $33.1(4.9)^{*}$ \\
\hline 20 & $5.2(3.3)$ & $26.8(5.8)^{*}$ & $10.5(5.7)$ & $10.3(5.2)$ & $6.6(3.7)$ & $8.4(3.9) *$ & $32.2(5.0)^{*}$ \\
\hline \multicolumn{8}{|c|}{ United Kingdom fixed private investment } \\
\hline 4 & $5.7(4.4)$ & $24.7(7.4)^{*}$ & $2.8(3.0)$ & $5.9(3.9)$ & $0.9(2.3)$ & $2.9(2.9)$ & $57.1(6.7)^{*}$ \\
\hline 8 & $10.6(4.8)^{*}$ & $21.7(6.0)^{*}$ & $4.0(2.8)$ & $6.2(3.6)$ & $2.5(2.7)$ & $8.3(3.6)^{*}$ & $46.8(5.6)^{*}$ \\
\hline 12 & $12.0(4.7)^{*}$ & $20.7(5.5)^{*}$ & $4.5(2.8)$ & $6.7(3.5)$ & $3.1(2.8)$ & $8.1(3.4)^{*}$ & $44.9(5.3)^{*}$ \\
\hline 16 & $11.9(4.5)^{*}$ & $20.5(5.4)^{*}$ & $4.7(2.8)$ & $6.5(3.3)$ & $4.1(2.9)$ & $8.1(3.2)^{*}$ & $44.3(5.2)^{*}$ \\
\hline 20 & $12.4(4.6)^{*}$ & $20.4(5.3)^{*}$ & $4.6(2.8)$ & $6.5(3.3)$ & $4.1(2.9)$ & $8.2(3.2)^{*}$ & $43.8(5.1)^{*}$ \\
\hline \multicolumn{8}{|c|}{ United States fixed private investment } \\
\hline 4 & $15.7(5.8)^{*}$ & $6.9(4.1)$ & $0.7(2.2)$ & $4.0(3.3)$ & $3.1(2.9)$ & $4.8(3.3)$ & $63.8(6.8)^{*}$ \\
\hline 8 & $7.3(3.7)$ & $52.5(8.3)^{*}$ & $1.9(2.6)$ & $2.2(2.4)$ & $4.4(3.4)$ & $5.0(3.2)$ & $26.7(5.3)^{*}$ \\
\hline 12 & $7.2(3.7)$ & $45.3(7.9)^{*}$ & $6.5(5.1)$ & $2.3(3.1)$ & $9.5(5.2)$ & $4.7(3.4)$ & $24.6(5.2)^{*}$ \\
\hline 16 & $7.1(3.5)$ & $45.1(7.5)^{*}$ & $7.0(5.0)$ & $2.2(3.2)$ & $9.8(5.1)$ & $4.8(3.3)$ & $24.0(4.8)^{*}$ \\
\hline 20 & $7.4(3.6)^{*}$ & $44.0(7.6)^{*}$ & $8.1(5.3)$ & $2.1(3.2)$ & $9.0(4.9)$ & $6.3(3.7)$ & $23.2(4.8)^{*}$ \\
\hline
\end{tabular}

Notes: The entry in each cell represents the point estimate for the percentage of the forecast error variance in FI explained by innovations to the indicated variable. SEs are in parenthesis. Point estimates are considered significant if they are twice as large as the SE.

* indicates the significance of the point estimate.

The VDCs for Canada are reported in the upper portion of Table 3. An analysis of Table 3 reveals that shocks to RGDP explain significant portions of the forecast error variance in Canada's FI. Depending on the time horizon, shocks to RGDP explain up to $18.6 \%$ of the forecast error variance in Canadian FI. Shocks to LR and to $\mathrm{Fl}$ itself also produce significant impacts on Fl. Perhaps most important for our study, shocks to HREX are insignificant at each time horizon and never explain more than $7.4 \%$ of the forecast error variance in Canadian FI. This result is similar to the finding for Canada reported in Campa and Goldberg (1999) and Harchaoui et al. (2005). Shocks to HRGDP also do not produce significant impacts on Canadian FI.

Table 3 also reports the VDCs for German Fl. The results in Table 3 indicate that shocks to Fl itself and shocks to RGDP, REX, and LR explain significant portions of the forecast error variance in German FI. At each time horizon, shocks to RGDP explain over $26 \%$ of the forecast error variance in FI, while shocks to REX explain over $10 \%$ of the forecast error variance at longer time horizons. Shocks to LR, although significant at longer time horizons, never explain over $8.5 \%$ of the forecast error variance in Fl. Our results for Germany also reveal that shocks to HRGDP and HREX never explain a significant portion of the forecast error variance in Fl.

Table 3 also displays VDCs for UK FI. In the United Kingdom, shocks to HRGDP or HREX never explain more than $4.7 \%$ of the forecast error variance in FI. These amounts are not significant. Hence, HRGDP and HREX are not a determinant of FDI in the United Kingdom. Further analysis of Table 3 reveals that shocks to $P, R G D P$ and $L R$ each explain significant portions of $\mathrm{Fl}$ in the United Kingdom. At the 20 
quarter horizon, shocks to $P$ explain $12.4 \%$ of the forecast error variance in $\mathrm{Fl}$, while shocks to $\mathrm{LR}$ explain $8.2 \%$ of the forecast error variance in FI. Shocks to RGDP are the main force behind FI in the United Kingdom. Regardless of the horizon, shocks to RGDP explain over $20 \%$ of the forecast error variance in UK FI.

The lower portion of Table 3 displays VDCs for US FI. Consistent with our results for Canada, Germany and the United Kingdom, in the United States, shocks to RGDP and shocks to FI explain significant portions of the forecast error variance in FI. The impact of shocks to RGDP on FI in the United States is quite strong. At longer time horizons, shocks to RGDP explain at least $44 \%$ of the forecast error variance in US FI. Shocks to HRGDP and HREX never explain a significant portion of the forecast error variance in $\mathrm{Fl}$ in the United States. This is contrary to the findings reported in Campa and Goldberg (1999). In the United States, shocks to $P$ have a significant impact on FI in some time horizons.

On balance, the VDC results in Table 2 show that RGDP is the most important determinant of FI in these countries. Shocks to HREX and shocks to HRGDP produce insignificant impacts on $\mathrm{Fl}$ in each country in our study. $\underline{\underline{10}}$

\section{Robustness Checks}

Many authors, including Blejer and Khan (1984), Aschauer (1989) and Ang (2009a), have argued that public (government) spending can crowd out, or crowd in, private investment spending. To test this hypothesis, we add the OECD's government final consumption expenditure (GOV) to the 'base model' for each country. $\underline{11}$

VDCs for models that include GOV appear in Table 4. $\underline{12}$ GOV is considered contemporaneously exogenous and is placed first in the Choleski ordering. The ordering of the other variables remains the same as in the base model. A comparison of Tables 3 and 4 reveals that major policy conclusions are unchanged when GOV is added to the base models.

Table 4. Variance decompositions of fixed investment final government consumption expenditure included model Choleski decomposition 


\begin{tabular}{|c|c|c|c|c|c|c|c|c|}
\hline \multicolumn{3}{|c|}{ Relative variation in } & \multicolumn{6}{|c|}{ Explained by innovations in } \\
\hline Horizon & GOV & $P$ & RGDP & HRGDP & REX & HREX & LR & FI \\
\hline \multicolumn{9}{|c|}{ Canadian fixed private investment } \\
\hline 4 & $8.7(4.2)^{*}$ & $0.9(3.2)$ & $13.1(5.1)^{*}$ & $0.4(2.8)$ & $2.9(5.7)$ & $6.2(4.5)$ & $17.1(5.2)^{*}$ & $50.7(9.2)^{*}$ \\
\hline 8 & $10.6(4.4)^{*}$ & $2.7(4.5)$ & $14.2(5.3)^{*}$ & $1.8(2.5)$ & $8.5(5.7)$ & $5.9(4.1)$ & $16.8(4.8)^{*}$ & $39.5(8.1)^{*}$ \\
\hline 12 & $12.8(4.6)^{*}$ & $3.6(4.5)$ & $14.1(4.9)^{*}$ & $3.9(2.7)$ & $9.8(6.2)$ & $5.8(3.8)$ & $15.5(4.3)^{*}$ & $34.6(7.8)^{*}$ \\
\hline 16 & $13.9(4.7)^{*}$ & $3.5(4.9)$ & $13.7(4.8)^{*}$ & $4.1(2.8)$ & $10.1(6.4)$ & $6.1(4.0)$ & $15.2(4.2)^{*}$ & $33.3(8.0)^{*}$ \\
\hline 20 & $14.1(4.9)^{*}$ & $3.6(5.4)$ & $13.4(4.8)^{*}$ & $4.3(2.9)$ & $10.2(6.6)$ & $6.2(4.2)$ & $15.7(4.2)^{*}$ & $32.5(8.5)^{*}$ \\
\hline \multicolumn{9}{|c|}{ German fixed private investment } \\
\hline 4 & $3.7(3.5)$ & $5.8(4.1)$ & $39.6(7.7)^{*}$ & $0.5(2.5)$ & $1.0(2.2)$ & $6.5(3.5)$ & $3.6(2.8)$ & $39.3(5.8)^{*}$ \\
\hline 8 & $4.0(3.3)$ & $4.9(3.1)$ & $29.7(6.2)^{*}$ & $5.8(4.8)$ & $8.0(4.4)$ & $7.0(3.6)$ & $9.3(3.5)^{*}$ & $31.0(4.5)^{*}$ \\
\hline 12 & $5.8(3.9)$ & $4.9(3.1)$ & $28.4(5.9)^{*}$ & $7.4(4.6)$ & $8.0(4.9)$ & $6.4(3.4)$ & $10.3(3.6)^{*}$ & $28.8(4.4)^{*}$ \\
\hline 16 & $6.0(4.3)$ & $4.9(3,1)$ & $27.5(5.7)^{*}$ & $7.9(4.7)$ & $9.0(4.9)$ & $6.5(3.6)$ & $10.5(3.8)^{*}$ & $27.7(4.4)^{*}$ \\
\hline 20 & $6.0(4.7)$ & $5.0(3.2)$ & $26.7(5.8)^{*}$ & $8.3(4.9)$ & $9.1(5.3)$ & $7.2(3.8)$ & $10.6(4.0)^{*}$ & $27.0(4.6)^{*}$ \\
\hline \multicolumn{9}{|c|}{ United Kingdom fixed private investment } \\
\hline 4 & $3.6(3.3)$ & $1.8(2.8)$ & $21.8(6.9)^{*}$ & $4.1(3.4)$ & $7.7(4.4)$ & $1.1(2.3)$ & $4.3(3.3)$ & $55.6(6.7)^{*}$ \\
\hline 8 & $4.0(3.0)$ & $8.7(4.0)^{*}$ & $18.3(5.5)^{*}$ & $5.2(3.0)$ & $8.2(3.9)^{*}$ & $3.2(2.8)$ & $9.0(3.8)^{*}$ & $43.4(5.3)^{*}$ \\
\hline 12 & $4.9(3.1)$ & $9.8(3.8)^{*}$ & $17.2(5.0)^{*}$ & $5.6(3.0)$ & $8.1(3.6)^{*}$ & $4.0(2.9)$ & $8.6(3.5)^{*}$ & $41.6(5.0)^{*}$ \\
\hline 16 & $5.3(3.1)$ & $10.0(3.6)^{*}$ & $16.5(4.7)^{*}$ & $5.9(3.0)$ & $7.6(3.3)^{*}$ & $5.2(3.0)$ & $8.9(3.4)^{*}$ & $40.6(4.8)^{*}$ \\
\hline 20 & $5.5(3.1)$ & $9.9(3.5)^{*}$ & $16.4(4.6)^{*}$ & $5.9(2.9)$ & $7.8(3.3)^{*}$ & $5.3(3.0)$ & $9.3(3.3)^{*}$ & $40.0(4.7)^{*}$ \\
\hline \multicolumn{9}{|c|}{ United States fixed private investment } \\
\hline 4 & $8.6(5.7)$ & $18.8(4.9)^{*}$ & $8.1(5.1)$ & $2.7(2.2)$ & $4.9(4.4)$ & $2.4(3.7)$ & $4.5(4.3)$ & $50.0(6.6)^{*}$ \\
\hline 8 & $9.1(7.0)$ & $9.5(3.7)^{*}$ & $43.9(7.3)^{*}$ & $2.4(3.8)$ & $4.7(7.5)$ & $2.6(3.6)$ & $4.0(3.8)$ & $23.7(4.8)^{*}$ \\
\hline 12 & $8.2(6.0)$ & $8.9(3.6)^{\circ}$ & $36.8(6.7)^{*}$ & $5.1(6.6)$ & $4.0(8.8)$ & $10.2(6.7)$ & $3.6(3.4)$ & $23.2(5.7)^{*}$ \\
\hline 16 & $9.8(5.8)$ & $8.6(3.6)^{*}$ & $39.0(7.2)^{*}$ & $5.1(5.9)$ & $4.1(10.0)$ & $9.8(6.5)$ & $3.2(3.1)$ & $20.3(5.1)^{*}$ \\
\hline 20 & $9.2(5.8)$ & $8.9(3.7)^{*}$ & $41.0(7.4)^{*}$ & $4.9(5.7)$ & $3.9(9.4)$ & $10.0(6.1)$ & $3.1(3.5)$ & $19.0(4.9)^{*}$ \\
\hline
\end{tabular}

Notes: The entry in each cell represents the point estimate for the percentage of the forecast error variance in FI explained by innovations to the indicated variable. SEs are in parenthesis. Point estimates are considered significant if they are twice as large as the $\mathrm{SE}$.

* indicates the significance of the point estimate.

Table 4 indicates that only in Canada do shocks to GOV explain a significant amount of the forecast error variance in FI. The largest VDC point estimate, 14.1\%, appears at horizon 20. $\underline{13}$ Policy implications for other model variables are unchanged with the addition of GOV to the Canadian model.

Although shocks to GOV do not have significant impacts on FI in Germany, the United Kingdom and the United States, there are slight differences in the VDCs for these countries when GOV is added to the base model. German REX explains a significant portion of the forecast error variance in German $\mathrm{FI}$ at horizons 8 and 16 when GOV is excluded from the model, but never explains a significant portion of the forecast error variance in German FI when GOV is included. UK REX explains a significant portion of the forecast error variance in UK FI when GOV is added to the model. However, for both Germany and the United Kingdom, point estimates of the impact of REX of FI change very little when GOV is added to the base model. For the United States, point estimates for the amount of forecast error variance in FI explained by $P$ shocks increase slightly when GOV is added to the model. This allows these point estimates to become significant at additional time horizons.

Using annual data for developing countries or panel data at an annual frequency, Ang (2009b, 2010) and Serven (2003) have demonstrated the importance of controlling for credit constraints in empirical models of fixed investment. Unfortunately, we were able to obtain consistent quarterly time series data on measures of bank credit for our estimation period for the United States only. 
The VDCs for a US VAR that includes the seasonally adjusted growth rate of real bank credit (BC) appear in Table 5. These VDCs were estimated placing BC first in the Choleski ordering. Table 5 indicates that the amount of the forecast error variance in US FI explained by shocks to BC is never significant. Comparing Tables 3 and 5 reveals that adding BC to the US VAR causes the amount of forecast error variance in FI explained by shocks to HREX to rise slightly.

\section{Table 5. Variance decompositions of fixed investment bank credit (BC) included Choleski decomposition}

\begin{tabular}{|c|c|c|c|c|c|c|c|c|}
\hline \multicolumn{3}{|c|}{ Relative variation in } & \multicolumn{6}{|c|}{ Explained by innovations in } \\
\hline Horizon & $\mathrm{BC}$ & $P$ & RGDP & HRGDP & REX & HREX & LR & FI \\
\hline \multicolumn{9}{|c|}{ United States fixed private investment } \\
\hline 4 & $7.6(4)$ & $9.6(4.8)^{*}$ & $3.5(3.1)$ & $1.1(2.4)$ & $3.9(3.4)$ & $4.1(3.2)$ & $4.3(3.1)$ & $66.0(7.0)^{*}$ \\
\hline 8 & $5.1(3.5)$ & $7.2(4.2)$ & $46.9(8.0)^{*}$ & $1.9(2.4)$ & $3.2(2.9)$ & $6.2(3.7)$ & $4.0(2.8)$ & $25.7(4.9)^{*}$ \\
\hline 12 & $7.1(4.5)$ & $6.6(3.8)$ & $38.1(7.3)^{*}$ & $5.2(4.1)$ & $3.5(3.4)$ & $12.8(5.7)^{*}$ & $3.8(3.0)$ & $23.0(4.5)^{*}$ \\
\hline 16 & $9.8(5.2)$ & $6.4(3.5)$ & $36.1(6.7)^{*}$ & $6.2(4.2)$ & $3.3(3.4)$ & $13.1(5.4)^{*}$ & $3.6(2.9)$ & $21.5(4.0)^{*}$ \\
\hline 20 & $9.1(4.9)$ & $6.4(3.5)$ & $36.3(7.0)^{*}$ & $8.3(4.7)$ & $3.4(3.6)$ & $11.4(5.0)^{*}$ & $4.7(3.2)$ & $20.5(4.1)^{*}$ \\
\hline
\end{tabular}

Notes: The entry in each cell represents the point estimate for the percentage of the forecast error variance in FI explained by innovations to the indicated variable. SEs are in parenthesis. Point estimates are considered significant if they are twice as large as the SE.

* indicates the significance of the point estimate.

\section{Conclusion}

This article re-examines the link between macroeconomic uncertainty and fixed private investment in four developed countries. The article looks at two different types of uncertainty - one emanating from the domestic economy and the other reflecting uncertainty in the external economy - measured by output and real exchange rate volatility. Using quarterly data for the 1972:1-2011:2 period, the article estimates four country-specific VAR models. Each model has seven variables. We estimate VDCs to examine the relationship among system variables.

The results yield important public policy implications with regard to the impact of volatility on private fixed investment. Shocks to neither the output nor exchange rate volatility explain a significant portion of the forecast error variance in private fixed investment in any country in our study.

\section{Notes}

${ }^{1}$ If the marginal investment and production cost $c$ is paid in foreign currency (i.e. the investment considered is a FDI), (7) does not change. This result may seem strange as we do add a price effect to the already considered demand effect; however, this is due to the absence of risk-aversion and to the absence of any trend in the evolution of the exchange rate.

${ }^{2}$ We deflate fixed private investment by the GDP deflator so that the real investment variable will be consistent across countries. Ideally, fixed private investment would be deflated by a price index for fixed investment. However, a quarterly price index that corresponds to our sample period for investment is available for the United States only. We have estimated a model for the United States where fixed private investment is deflated by the deflator for fixed investment. This substitution leaves policy implications unchanged.

${ }^{3}$ For Canada, the United Kingdom and the United States, the long-term rate of interest is the yield on 10-year government bonds. For Germany, the interest rate on 9-10 year plus government bonds is used. 
${ }^{4}$ The real effective exchange rate is a chain-weighted index that takes into account the nominal exchange rate and the CPI's of the thirty OECD member countries and 16 other countries. The weighting takes into account relative market shares held by each country's competitors.

${ }^{5}$ The MEI reports REX in seasonally unadjusted form. Because REX is calculated, in part, with the CPI of various countries, and it is likely that REX contains seasonal components. We seasonally adjust REX for each country using the $\mathrm{X}-11$ procedure in SAS.

${ }^{6}$ In general, the GARCH estimates in Tables 1 and 2 appear to be reasonable. The exception to this is the GARCH term in the equation for the UK's REX. This term is statistically significant, and implausibly, negative.

${ }^{7}$ The models for Canada and Germany also contain an error correction term. All VAR equations contain a constant.

${ }^{8}$ Variables lower in the ordering do not contemporaneously influence variables higher in the ordering.

${ }^{9} \mathrm{FI}$ does have an influence on other system variables through the lags in the VAR.

${ }^{10}$ We have also calculated impulse response functions (IRFs) that examine the impact of shocks to HREX and HRGDP on FI for each country in our study. These IRFs also indicate that shocks to HREX and HRGDP do not product meaningful impacts on FI. In each case, at most two of twenty IRFs coefficients are significant, and those coefficients that are significant are extremely small in absolute value.

${ }^{11}$ Government final consumption expenditure provides a consistent measure across countries; the measure of government final consumption expenditure we use is an index number expressed in constant prices.

${ }^{12}$ Unit root tests were conducted on GOV. The log level of GOV is I(1) for each country and is difference once before the estimation of the corresponding VAR or VEC. Johansen's (1988 Johansen, S. (1988) Statistical analysis of cointegration vectors, Journal of Economic Dynamics and Control, 12, 169-210.[Crossref], [Web of Science ${ }^{\circledR}$ ], [Google Scholar]) rank test indicates one cointegrating vector for the United States when GOV is added to the model. Without GOV in the US model, cointegration was not present. The US VDCs reported in Table 4 are derived from a VEC. Adding GOV to the models for the other countries in the study does not change the order of cointegration.

${ }^{13}$ Canada's impulse response function for the impact of a shock to GOV on FI indicates that a shock to GOV has a positive and significant impact on FI for the first two periods following the shock and insignificant impact thereafter. This indicates a short lived complementary impact of government expenditures on Canada's private investment (crowding in).

\section{References}

Abel, A. B. (1983) Optimal investment under uncertainty, The American Economic Review, 73, 228-33.

Ang, J. B. (2009a) Do public investment and FDI crowd in or crowd out private domestic investment in Malaysia?, Applied Economics, 41, 913-19. doi:10.1080/00036840701721448

Ang, J. B. (2009b) Private investment and financial sector policies in India and Malaysia, World Development, 37, 1261-73. doi:10.1016/j.worlddev.2008.12.003

Ang, J. B. (2010) Determinants of private investment in Malaysia: what causes the post-crisis slumps?, Contemporary Economic Policy, 28, 378-91.

Aschauer, D. A. (1989) Does public capital crowd out private capital?, Journal of Monetary Economics, 24, 17188. doi:10.1016/0304-3932(89)90002-0

Blejer, M. I. and Khan, M. S. (1984) Government policy and private investment in developing countries, Staff Papers - International Monetary Fund, 31, 379-403. doi:10.2307/3866797

Box, G. and Jenkins, G. (1976) Time Series Analysis, Forecasting, and Control, Holden Day, San Francisco.

Byrne, J. and Davis, E. P. (2003) Panel estimation of the impact of exchange rate uncertainty on investment in the major industrial countries, NIESR Discussion Paper No 208, NIESR, London.

Caballero, R. J. (1991) On the sign of the investment-uncertainty relationship, The American Economic Review, $81,279-88$.

Campa, J. and Goldberg, L. S. (1995) Investment in manufacturing, exchange rates and external exposure, Journal of International Economics, 38, 297-320. doi:10.1016/0022-1996(94)01348-V 
Campa, J. and Goldberg, L. S. (1997) The evolving external orientation of manufacturing: a profile of four countries, Federal Reserve Bank of New York Economic Policy Review, 3, 53-81.

Campa, J. and Goldberg, L. S. (1999) Investment, pass-through, and exchange rates: a cross-country comparison, International Economic Review, 40, 287-314. doi:10.1111/1468-2354.00016

Carruth, A., Dickerson, A. and Henley, A. (2002) What do we know about investment under uncertainty?, Journal of Economic Surveys, 16, 119-53.

Chowdhury, A. R. and Wheeler, M. (2008) Does real exchange rate volatility affect foreign direct investment? Evidence from four developed economies, The International Trade Journal, 22, 218-45. doi:10.1080/08853900801970601

Courchene, T. J. and Harris, R. G. (1999) From Fixing to Monetary Union: Options for North American Currency Integration, C.D. Howe Institute, Commentary No. 127, Toronto, 1-28.

Craine, R. (1989) Risky business: the allocation of capital, Journal of Monetary Economics, 23, 201-18. doi:10.1016/0304-3932(89)90048-2

Darby, J., Hughes Hallett, A. H., Ireland, J. et al. (1999) The impact of exchange rate uncertainty on the level of investment, Economic Journal, 109, 55-67. doi:10.1111/1468-0297.00416

Darby, J., Hughes Hallett, A. J., Ireland, J. et al. (2002) Exchange Rate Uncertainty and Business Sector Investment, Department of Economics, University of Strathclyde, Glasgow.

Dickey, D. and Fuller, A. W. (1979) Distribution of the estimators for time series regressions with a unit root, Journal of the American Statistical Association, 74, 427-31.

Dixit, A. and Pindyck, R. S. (1994) Investment under Uncertainty, Princeton University Press, Princeton.

Emerson., M., Gros, D., Italianer, A. et al. (1992) One Market, One Money, Oxford University Press, Oxford.

Engle, R. F. and Granger, C. W. J. (1987) Co-integration and error correction: representation, estimation, and testing, Econometrica, 55, 251-76. doi:10.2307/1913236

Goldberg, L. S. (1993) Exchange rates and investment in United States industry, The Review of Economics and Statistics, 75, 575-89. doi:10.2307/2110011

Gordon, R. J. and Veitch, J. M. (1989) Fixed investment in the American business cycle, 1919-83, in The American Business Cycle, Gordon, R. J. (Ed), University of Chicago Press, Chicago, IL, pp. 267-357.

Greenwald, B., Stiglitz, J. E. and Weiss, A. (1984) Informational imperfections in the capital market and macroeconomic fluctuations, The American Economic Review, 74, 194-99.

Guérin, J.-L. and Lahrèche-Révil, A. (2001) Exchange Rate Volatility and Growth, mimeo, Bank of Canada, Ottowa, ON.

Harchaoui, T., Tarkhani, F. and Yuen, T. (2005) The Effects of the Exchange Rate on Investment: Evidence from Canadian Manufacturing Industries, Bank of Canada WP, Bank of Canada, Ottowa, ON.

Hartman, R. (1972) The effects of price and cost uncertainty on investment, Journal of Economic Theory, 5, 25866. doi:10.1016/0022-0531(72)90105-6

Johansen, S. (1988) Statistical analysis of cointegration vectors, Journal of Economic Dynamics and Control, 12, 169-210.

Johansen, S. (2000) A Bartlett correction factor for tests on the cointegrating relations, Econometric Theory, 16, 740-78. doi:10.1017/S0266466600165065

Johansen, S. (2002) A small sample correction for the test of cointegrating rank in the vector autoregressive model, Econometrica, 70, 1929-61. doi:10.1111/1468-0262.00358

Johansen, S. and Juselius, K. (1990) Maximum likelihood estimation and inference on cointegration-with applications to money demand, Oxford Bulletin of Economics and Statistics, 52, 169-210.

Kwiatkowski, D., Phillips, P. C. B., Schmidt, P. et al. (1992) Testing the null hypothesis of stationarity against the alternative of a unit root, Journal of Econometrics, 54, 159-78. doi:10.1016/0304-4076(92)90104-Y

Lafrance, R. and Schembri, L. L. (2000) The exchange rate, productivity, and the standard of living, Bank of Canada Review, 17-28.

Lafrance, R. and Tessier, D. (2000) Exchange rate variability and investment in Canada, in Proceedings of the Revisiting the Case for Flexible Exchange Rates, Bank of Canada, Ottowa, ON, pp. 239-68. 
Lee, J. and Shin, K. (2001) The role of variable input in the relationship between investment and uncertainty, American Economic Review, 91, 667-80.

Nucci, F. and Pozzolo, A. (2001) Investment and the exchange rate, Discussion Paper, Banca d'Italia, Rome.

Ogawa, K. and Suzuki, K. (2000) Uncertainty and investment: some evidence from the panel data of Japanese manufacturing firms, The Japanese Economic Review, 51, 170-92. doi:10.1111/1468-5876.00145

Oliveira-Martins, J., Scarpetta, S. and Pilat, D. (1996) Mark-up ratios in manufacturing industries, estimates for 14 OECD countries, OECD Economic Department Working Paper No. 162, OECD, Paris.

Pindyck, R. S. (1991) Irreversibility, uncertainty, and investment, Journal of Economic Literature, 29, 1110-48.

Serven, L. (1998) Macroeconomic uncertainty and private investment in LDCs: an empirical investigation, Policy Research Working Paper Series No. 2035, The World Bank, Washington, DC.

Serven, L. (1999) Terms of trade shocks and optimal investment: another look at the Laursen-Metzler effect, Journal of International Money and Finance, 18, 337-65. doi:10.1016/S0261-5606(99)85001-3

Serven, L. (2003) Real exchange rate uncertainty and private investment in developing countries, Review of Economic and Statistics, 212-18. doi:10.1162/rest.2003.85.1.212 